\title{
Wolbachia strains in cryptic species of the Anastrepha fraterculus complex (Diptera, Tephritidae) along the Neotropical Region
}

\author{
Leandro F. Prezotto ${ }^{a}$, André L.P. Perondini ${ }^{a}$, Vicente Hernández-Ortiz ${ }^{b}$, Celso L. Marino ${ }^{c}$, \\ Denise Selivon ${ }^{\mathrm{a}, *}$ \\ a Departamento de Genética e Biologia Evolutiva, Instituto de Biociências, Universidade de São Paulo, São Paulo, Brazil \\ ${ }^{\mathrm{b}}$ Red de Interacciones Multitróficas, Instituto de Ecología A.C., Xalapa, Veracruz, Mexico

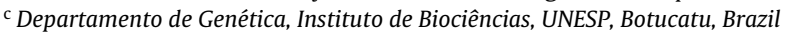

\section{A R T I C L E I N F O}

\section{Article history:}

Received 15 July 2016

Received in revised form 1 November 2016

Accepted 5 November 2016

\section{Keywords:}

Fruit flies

Bacteria

MLST

WSP Typing

Recombination

Phylogeny

\begin{abstract}
A B S T R A C T
Infection by Wolbachia was described previously in eleven species of Anastrepha fruit flies some of which are important pests of fruticulture. One such species is the nominal Anastrepha fraterculus, the South American fruit fly, which actually comprises a complex of cryptic species. The suggestions of using Wolbachia for the control of these pest species, make imperative a more precise characterization of the existing strains of the bacteria. In this study, population samples of the A. fraterculus complex from Brazil, Argentina, Peru, Ecuador, Colombia, Guatemala and Mexico were analyzed for Wolbachia infection. The bacteria were genotyped by the MLST and WSP Typing methodologies. All samples were infected with Wolbachia of supergroup "A". For each of the five MLST genes, unique as well as already known alleles were detected. Nineteen sequence types for the concatenated sequences of the five MLST genes, and twenty wsp alleles were found in the samples. Host-specific haplotypes, shared strains among distinct hosts, and more than one strain of Wolbachia were found in some population samples. Recombination among the MLST genes and intragenic recombination between wsp haplotypes was rare. Phylogenetic analysis showed a great similarity among the Wolbachia strains in the A. fraterculus complex. However, some strains of Wolbachia are found throughout the Neotropical Region and there are specific strains in determined geographical areas.
\end{abstract}

(c) 2016 Elsevier GmbH. All rights reserved.

\section{Introduction}

The bacteria Wolbachia found in both somatic and reproductive tissues of many species of arthropods and nematodes, has been shown to be associated with several effects in the reproduction of their hosts, such as cytoplasmic incompatibility (CI), parthenogenesis, feminization of genetic males and male killing [9,60,61]. The relationship between Wolbachia and their hosts varies in some cases evolving from a parasitic to a mutualistic condition [43,52,61].

Among frugivorous tephritid flies hosts Wolbachia infection was found to induce $\mathrm{CI}$ as showed in transinfected Bactrocera oleae [1] and Ceratitis capitata [65,66], and most likely in Rhagoletis cerasi

\footnotetext{
* Corresponding author at: Departamento de Genética e Biologia Evolutiva, Instituto de Biociências, Universidade de São Paulo, Rua do Matão, 277, 05088-900, São Paulo, Brazil. Fax: +55 1130917553 .

E-mail addresses: leandroprezotto@yahoo.com.br

(L.F. Prezotto), alpperon@ib.usp.br (A.L.P. Perondini),vicente.hernandez@inecol.mx (V. Hernández-Ortiz), clmarino@ibb.unesp.br (C.L. Marino), dselivon@ib.usp.br (D. Selivon)
}

[38]. Hence, their use in programs for suppression of fruit fly populations was proposed and tested $[1,9,65,66]$.

In fruit flies of genus Anastrepha, endemic to the Neotropical Region, Wolbachia was found infecting 12 species $[10,12,27,28,50,62]$, many of which are of economic importance such as those that belong to five infrageneric taxonomic groups, fraterculus, grandis, pseudoparalella, striata and serpentina [32]. The fraterculus species group received particular attention in recent years because it includes many of the pest species. One of the most important is the "South American fruit fly", Anastrepha fraterculus (Wiedemann) [63]. This nominal species actually comprises a complex of cryptic species, the $A$. fraterculus complex (AF complex), which is currently being characterized $[10,11,17,18,46-49,51,55,58]$. Morphometric analyses disclosed eight morphotypes within the AF complex, "Mexican" (with samples from Mexico and Central America), "Venezuelan" (from lowlands of Venezuela), "Andean" (from highlands of Venezuela and Colombia), "Peruvian" (from lowlands of Ecuador and Peru), "Ecuadorian" (from highlands of Ecuador and Peru), and three Brazilian morphotypes, "Brazilian-1" (A. sp.1 from Brazil and 
Argentina), “Brazilian-2" (A. sp.2), and “Brazilian-3" (A. sp.3) $[17,18]$.

Crosses between AF complex morphotypes resulted in low viability of hybrid progenies due to several pre-zygotic and/or post-zygotic incompatibilities [10,13,14,40,45,48,49,59]. Since Brazilian-1 and Brazilian-2 morphotypes were found to be infected by Wolbachia, it was suggested that Wolbachia could be involved in the zygotic inviability observed in laboratory crosses [49,50]. However, a posterior study involving samples from Brazil, Argentina and Peru, similarities of Wolbachia wsp gene led to the suggestion that the bacteria would not be involved in the observed zygotic inviabilities [10]. However, the observed similarities of Wolbachia was determined just by analysis of the highly conserved regions (CRs) of the Wolbachia wsp gene, excluding the hypervariable regions of the gene.

So far, Wolbachia infecting the morphotypes of the AF complex were characterized by analysis of gene $f t s Z[25,50]$ but mostly by gene wsp $[10,12,25]$. Recently, Wolbachia was found in five population samples of Brazilian-1 (A. sp.1 aff. fraterculus) but no details were given about the existing wsp alleles in the samples [14]. As is already known, a more reliable identification of strains is achieved when an approach of the MLST type (Multi Locus Sequence Typing) is applied. Such methodology, developed for Wolbachia [6,7,8,34], was employed successfully in fruit flies species of genera Bactrocera and Dacus [20,22,30,31], Rhagoletis [2,3,41] and Anastrepha [27].

In the present report, we describe results of the characterization of Wolbachia strains in samples of the A. fraterculus complex collected along the Neotropical Region using the MLST and the WSP Typing methodologies. The data show the existence of strains already known in the WSP data base, of several novel strains, the rare presence of putative recombinant sequences and a close phylogenetic relationship among the strains within this species complex.

\section{Material and methods}

\section{Fruit fly samples}

Samples of the AF complex from 48 locations along the Neotropical Region, including Brazil, Argentina, Peru, Ecuador, Colombia, Guatemala and Mexico (Fig. 1), were screened for Wolbachia infection. The analyzed adult flies from Brazil were obtained from infested fruits brought to the laboratory. After emergence, adult flies were preserved in ethanol at $-20^{\circ} \mathrm{C}$. The samples from other localities along the Neotropical Region were obtained from batches of flies previously employed in morphometric analysis of the $\mathrm{AF}$ complex, which were preserved in ethanol [17]. Localities where the host fruits were collected are listed in Table 1.

\section{DNA extraction, amplification and sequencing of gene fragments}

DNA was extracted from single flies according to method previously used for Anastrepha [12], and Wolbachia infection was screened by the MLST and WSP Typing methodologies [6,7]. Amplification of the five MLST genes was made with the primers described by Baldo et al. [6]. The PCR cycles were of 2 min at $94^{\circ} \mathrm{C}$, 37 cycles ( $30 \mathrm{~s}$ at $94^{\circ} \mathrm{C}, 45 \mathrm{~s}$ of annealing at $54^{\circ} \mathrm{C}$ for ftsZ, gatB, hcpA $\operatorname{cox} A$, and $59^{\circ} \mathrm{C}$ for $\left.f b p A\right), 1 \mathrm{~min} 30 \mathrm{~s}$ at $72^{\circ} \mathrm{C}$, followed by $10 \mathrm{~min}$ at $72{ }^{\circ} \mathrm{C}$. For the $w s p$ gene, the primers $81 \mathrm{~F}$ and $691 \mathrm{R}$ [67], were used. The PCR steps were as follow: one cycle of $2 \mathrm{~min}$ at $95^{\circ} \mathrm{C}$, followed by 35 cycles $\left(1 \mathrm{~min}\right.$ at $95^{\circ} \mathrm{C}, 1 \mathrm{~min}$ at $55^{\circ} \mathrm{C}, 1 \mathrm{~min}$ at $75^{\circ} \mathrm{C}$ ), and a final cycle of $10 \mathrm{~min}$ at $72^{\circ} \mathrm{C}$. Infected samples of $\mathrm{C}$. capitata [39] were used as positive control of amplification. As control for negative amplification the DNA templates were tested by amplification of gene 28S rDNA with primers and PCR conditions described by Werren et al. [62]. Samples that continued to be negative were discarded only after new DNA concentrations for amplification were tested, and in cases of persistent negative results new extractions were made on the samples. The amplified fragments were sequenced using primers DF2 and DR2 and the BigDye 2.0 kit for automated sequencing in an ABI Prism Automatic Sequencer (Applied Biosystems). Inspection of the electropherogram of each amplified fragment with the web tool Electropherogram Quality Analysis [57] showed no sequences with signals of slippage or double peaks. Furthermore, when identical sequences were obtained in two-five individuals in a given sample, the sequences were considered as free of PCR errors. In the samples where single sequences were obtained from single individuals, the PCR was repeated on the same DNA template to confirm the sequence data [44]. Furthermore, the conceptual amino acid translations of the sequences without interruptions also indicated that the sequences had no PCR artifacts [64].

\section{Analyses of sequences, recombination and phylogenetic inferences}

The obtained sequences aligned using the Clustal Omega [53] were adjusted manually and the haplotypes identified by the DnaSP 5.10 software [23]. The concatenated five genes used in the MLST methodology ( $g a t B, \operatorname{cox} A, h c p A$, ftsZ and $f b p A$ ) were analyzed according to Baldo et al. [6], and the wsp gene according to the WSP Typing protocol [7]. Blast of the sequences to the NCBI and to the Wolbachia Database (http://www.pubmlst.org/wolbachia/) identified sequences already described in other insects. Sequences that had no matches were submitted to the curators for assignment of novel identification numbers. The sequences were deposited in the Wolbachia Database and may be accessed by their MLST and wsp codes or by the identification numbers (ID 1777-1803), and in the GenBank (accession numbers KX129130-KX129171). Evidences for recombination between sequences were tested by three methods, Maxchi [29], Geneconv [33] and Chimaera [35] implemented in the RDP3.5 software [26]. The intragenic recombination between wsp sequences was also analyzed by the HVRs amino acid profiles according to the WSP Typing methodology [7]. Gene wsp is highly variable and is organized in four hypervariable regions (HVRs) which are separated one from the other by conserved nucleotide sequences (CRs). Alleles of the wsp gene are identified by a code composed of four numbers each one related to the amino acid sequence of each HVR plus half of its contiguous CR [7].

The phylogenetic analyses using Maximum-Likelihood (ML) implemented in the PhyML 3.1 program [15] were conducted for a concatenated data set of the five MLST genes and for wsp gene apart. The percentage of replicate trees in which the associate strain clustered together was measured by boostrap tests (1000 replicates). The best evolutionary model was chosen according to the AICc (Akaike Information Criterion, corrected) implemented in MEGA6 [56]. Sequences of Wolbachia strains infecting other insects (outgroups), may be assessed in the Wolbachia Database (isolates/search) by their ID codes. The ID identify simultaneously the strains based on the allelic codes of the five MLST genes and of gene wsp: Anastrepha striata (ID307), Bactrocera decurtans (ID560), Bactrocera tryoni (ID559), Drosophila bifasciata (ID5), Drosophila orientacea(ID9), Drosophila simulans(ID11), Ephestia kuehniella(ID13), Solenopsis invicta (ID2) and Agelenopsis longistyla (ID179).

\section{Results}

Six of the eight morphotypes of the AF complex [17,18] were employed in the analyses: Brazilian-1 (A.sp.1 and Argentina), Brazilian-2 (A. sp.2), Brazilian-3 (A. sp.3), Peruvian [Ecuador ( $A$. sp.4) and Peru], Andean (Colombia), and Mexican (Guatemala and Mexico). Out of 260 individual flies of the AF complex screened for 


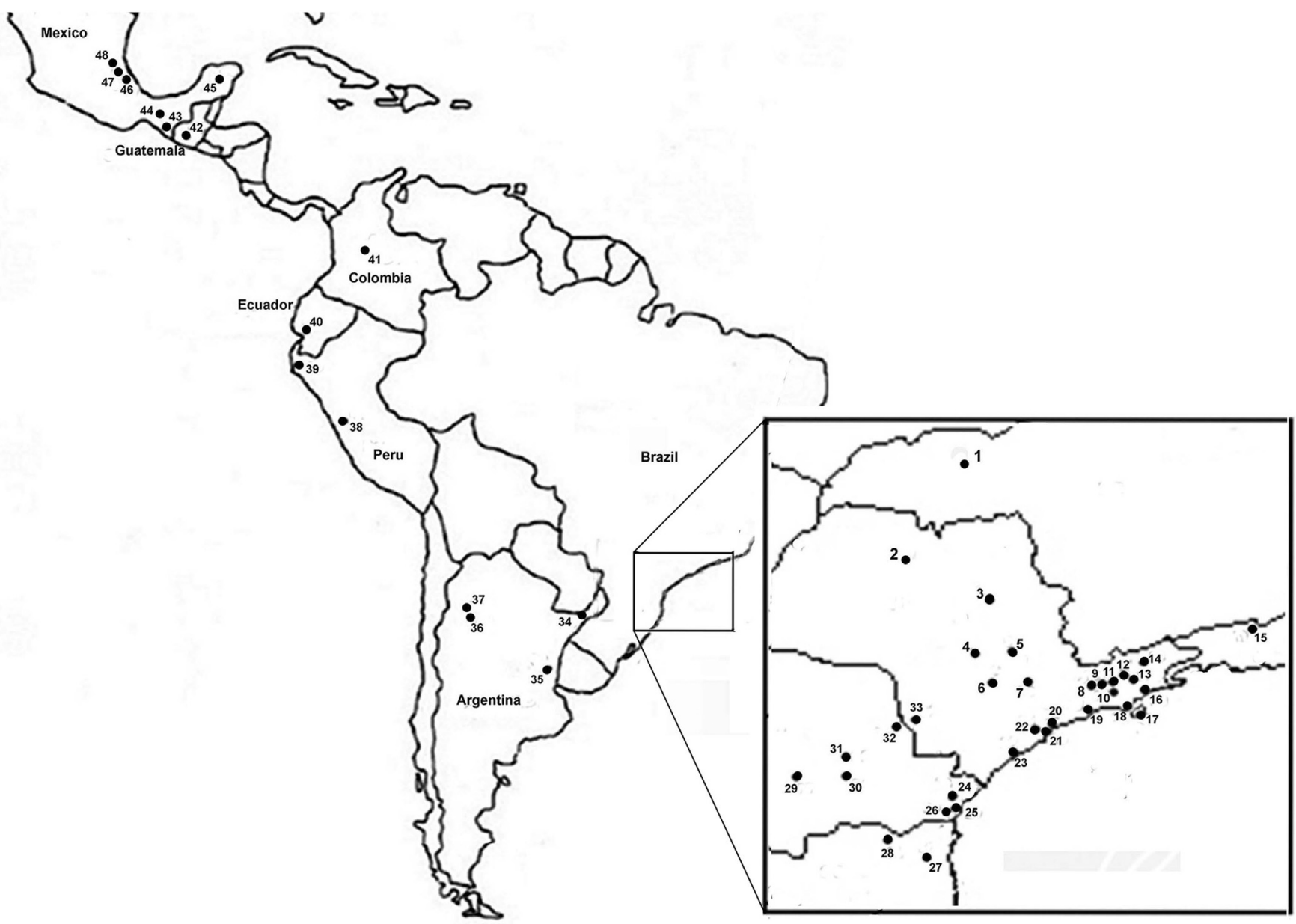

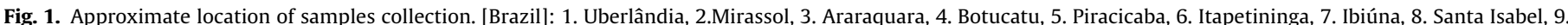

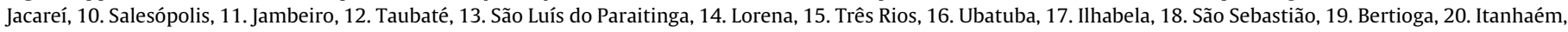

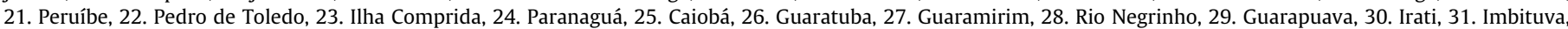

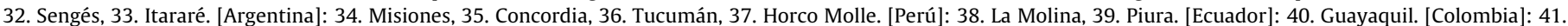
Tolima.[Guatemala]: 42. Guatemala City. [México]: 43. Tapachula, 44. San Vicente, 45. Quintana Roo, 46.Teocelo, 47. Apazapan, 48. La Jicayana.

Wolbachia, 255 were found to be infected (Tables 2 and 3). Only one individual in each of four samples from Mexico (Jicayana, Teocelo, Tapachula and San Vicente), and in the sample from Concordia (Argentina) were not infected.

\section{MLST genotyping}

The MLST analysis showed the existence of seven gatB, four $\operatorname{cox} A$, six $h c p A$, eight $f t s Z$ and nine $f p b A$ alleles. The data also shows the presence of new alleles for the five loci: five for gat $B$, three for $\operatorname{cox} A$, five for $h c p A$, six for $f t s Z$ and eight for $f p b A$. Moreover, the analysis identified 19 sequence types (STs) determined by the combination of alleles of the five MLST genes among the morphotypes of the AF complex (Table 2), and that Wolbachia strains infecting the AF morphotypes belong to supergroup A. Two sequence types, ST-1 and ST-13, previously known for Wolbachia infecting many insect species, and 17 new strains not found in the MLST database were detected (Table 2). ST-1 was the most common strain found in $69 \%$ (176 out 255) individuals, occurring in 17 samples of Brazilian1, 11 samples of Brazilian-2, 10 samples of Brazilian-3, and also in one sample of Peruvian (Piura) and Mexican (Tapachula) morphotypes. ST-13 was found in $6.2 \%$ (16 out 255 ) of the individuals, from three Brazilian-1 samples (Itapetininga, Mirassol, Salesópolis), and one sample of Brazilian-2 (Taubaté). Out of the 17 new STs, only four were found as single sequence from single analyzed flies, ST-329 (Jacarei) and ST-330 (Salesópolis) found in Brazilian1, ST-332 in Brazilian-3 (Salesópolis), and ST-336 found in Mexican (Apazapan) morphotypes. The majority of samples were infected by single strains, and two morphotypes, Brazilian-1 (Sengés) and Brazilian-3 (Salesópolis), shared a same strain (ST-331). Moreover, infections by two distinct strains (in distinct individuals) were found in Brazilian-1 (Jacarei: ST-1, ST-329; Salesópolis: ST-13, ST330), in Brazilian-3 (Salesópolis: ST-1, ST-332), and in Mexican (Apazapan: ST-335, ST-336) morphotypes (Table 2). The differences among strains for the five genes are due to scattered synonymous and nonsynonymous nucleotide substitutions (Table S1) without any nucleotide gaps. Variability of the each MLST genes is low, from 0.0005 (coxA) to 0.0019 ( $h c p A$ and ftsZ) (Table S2), as well as the variability of the strains within each morphotype, from 0.0001 (Brazilian-2) to 0.0027 (Peruvian). The overall genetic distances between the morphotypes are lower than $1 \%$ (Table S3).

\section{WSP Typing}

Genotyping of wsp was made by the WSP Typing methodology [7] revealing the presence of nine HVR1, eight HVR2, three HVR3 and 13 HVR4 variants. Within these variants eight HVR1, seven HVR2, two HVR3 and eleven HVR4 were new haplotypes. The analysis confirms the results of the MLST data by showing that the wsp sequences belong to Wolbachia of supergroup A. The HVR analy- 
Table 1

Localities, codes, geographic coordinates and sampled host fruits or laboratory colonies in the Neotropical Region.

\begin{tabular}{|c|c|c|c|c|}
\hline Localities & & Codes & Coordinates & Host fruits \\
\hline \multirow[t]{33}{*}{ Brazil } & Uberlândia & Ube & $18^{\circ} 56^{\prime} 46^{\prime \prime} \mathrm{S}, 48^{\circ} 13^{\prime} 55^{\prime \prime W}$ & Guava (Psidium guajava) \\
\hline & Mirassol & Mir & $20^{\circ} 49^{\prime} 07^{\prime \prime} \mathrm{S}, 49^{\circ} 30^{\prime} 30^{\prime \prime W}$ & Guava \\
\hline & Araraquara & Ara & $21^{\circ} 47^{\prime} 38^{\prime \prime} \mathrm{S}, 48^{\circ} 10^{\prime} 33^{\prime \prime} \mathrm{W}$ & Guava \\
\hline & Botucatu & Bot & $22^{\circ} 56^{\prime} 18^{\prime \prime} \mathrm{S}, 48^{\circ} 18^{\prime} 25^{\prime \prime} \mathrm{W}$ & Guava \\
\hline & Piracicaba & Pir & $22^{\circ} 43^{\prime} 30^{\prime \prime} \mathrm{S}, 47^{\circ} 38^{\prime} 56^{\prime \prime} \mathrm{W}$ & Guava \\
\hline & Itapetininga & Itp & $23^{\circ} 35^{\prime} 31^{\prime \prime} \mathrm{S}, 48^{\circ} 03^{\prime} 10^{\prime \prime} \mathrm{W}$ & Guava \\
\hline & Ibiuna & Ibi & $23^{\circ} 39^{\prime} 21^{\prime \prime} \mathrm{S}, 47^{\circ} 13^{\prime} 22^{\prime \prime} \mathrm{W}$ & Guava \\
\hline & Santa Isabel & Isa & $23^{\circ} 19^{\prime} 00^{\prime \prime} \mathrm{S}, 46^{\circ} 13^{\prime} 25^{\prime \prime} \mathrm{W}$ & Guava \\
\hline & Jacarei & Jac & $23^{\circ} 18^{\prime} 18^{\prime \prime} \mathrm{S}, 44^{\circ} 41^{\prime} 16^{\prime \prime W}$ & Guava \\
\hline & Salesópolis & Sal & $23^{\circ} 31^{\prime} 51^{\prime \prime} \mathrm{S}, 45^{\circ} 50^{\prime} 30^{\prime \prime} \mathrm{W}$ & Guava \\
\hline & Jambeiro & Jam & $23^{\circ} 15^{\prime} 14^{\prime \prime} \mathrm{S}, 45^{\circ} 07^{\prime} 30^{\prime \prime} \mathrm{W}$ & Guava \\
\hline & Taubaté & Tau & $23^{\circ} 01^{\prime} 33^{\prime \prime} \mathrm{S}, 45^{\circ} 33^{\prime} 31^{\prime \prime} \mathrm{W}$ & Guava; Orange (Citrus sp.) \\
\hline & São Luiz do Paraitinga & Slp & $23^{\circ} 13^{\prime} 24^{\prime \prime} \mathrm{S}, 45^{\circ} 18^{\prime} 47^{\prime \prime} \mathrm{W}$ & Guava \\
\hline & Lorena & Lor & $22^{\circ} 43^{\prime} 51^{\prime \prime} \mathrm{S}, 45^{\circ} 07^{\prime} 30^{\prime \prime} \mathrm{W}$ & Guava \\
\hline & Três Rios & Tri & $22^{\circ} 07^{\prime} 21^{\prime \prime} \mathrm{S}, 43^{\circ} 12^{\prime} 47^{\prime \prime} \mathrm{W}$ & Guava \\
\hline & Ubatuba & Uba & $22^{\circ} 46^{\prime} 24^{\prime \prime} \mathrm{S}, 45^{\circ} 41^{\prime} 52^{\prime \prime} \mathrm{W}$ & Tropical almond (Terminalia cattapa) \\
\hline & Ilhabela & Ilh & $23^{\circ} 48^{\prime} 22^{\prime \prime} \mathrm{S}, 45^{\circ} 21^{\prime} 54^{\prime \prime} \mathrm{W}$ & Guava \\
\hline & São Sebastião & Sse & $23^{\circ} 45^{\prime} 22^{\prime \prime} \mathrm{S}, 45^{\circ} 24^{\prime} 54^{\prime \prime} \mathrm{W}$ & Tropical almond; orange \\
\hline & Bertioga & Ber & $23^{\circ} 51^{\prime} 14^{\prime \prime} \mathrm{S}, 46^{\circ} 08^{\prime} 20^{\prime \prime} \mathrm{W}$ & Tropical almond \\
\hline & Itanhaém & Ita & $24^{\circ} 10^{\prime} 58^{\prime \prime} \mathrm{S}, 46^{\circ} 47^{\prime} 20^{\prime \prime} \mathrm{W}$ & Tropical almond \\
\hline & Peruibe & Per & $24^{\circ} 19^{\prime} 12^{\prime \prime} \mathrm{S}, 46^{\circ} 59^{\prime} 52^{\prime \prime} \mathrm{W}$ & Tropical almond \\
\hline & Pedro de Toledo & Pto & $24^{\circ} 16^{\prime} 30^{\prime \prime S}, 47^{\circ} 13^{\prime} 58^{\prime \prime W}$ & Guava; Orange \\
\hline & Ilha Comprida & Ico & $24^{\circ} 44^{\prime} 27^{\prime \prime} \mathrm{S}, 47^{\circ} 32^{\prime} 24^{\prime \prime} \mathrm{W}$ & Tropical almond \\
\hline & Paranaguá & Par & $25^{\circ} 31^{\prime} 12^{\prime \prime} \mathrm{S}, 48^{\circ} 30^{\prime} 32^{\prime \prime} \mathrm{W}$ & Tropical almond \\
\hline & Caiobá & Cai & $25^{\circ} 49^{\prime} 04^{\prime \prime} \mathrm{S}, 48^{\circ} 32^{\prime} 34^{\prime \prime} \mathrm{W}$ & Tropical almond \\
\hline & Guaratuba & Gut & $25^{\circ} 52^{\prime} 58^{\prime \prime} \mathrm{S}, 48^{\circ} 34^{\prime} 30^{\prime \prime W}$ & Tropical almond \\
\hline & Guaramirim & Gum & $26^{\circ} 28^{\prime} 23^{\prime \prime} \mathrm{S}, 49^{\circ} 00^{\prime} 10^{\prime \prime} \mathrm{W}$ & Guava \\
\hline & Rio Negrinho & Rne & $26^{\circ} 15^{\prime} 14^{\prime \prime S}, 49^{\circ} 31^{\prime} 04^{\prime \prime W}$ & Guava \\
\hline & Guarapuava & Gua & $25^{\circ} 23^{\prime} 42^{\prime \prime} \mathrm{S}, 51^{\circ} 27^{\prime} 28^{\prime \prime} \mathrm{W}$ & Guava \\
\hline & Iratí & Ira & $25^{\circ} 28^{\prime} 10^{\prime \prime} \mathrm{S}, 50^{\circ} 39^{\prime} 30^{\prime \prime} \mathrm{W}$ & Guava \\
\hline & Imbituva & $\operatorname{Imb}$ & $25^{\circ} 13^{\prime} 48^{\prime \prime S}, 50^{\circ} 36^{\prime} 16^{\prime \prime W}$ & Guava \\
\hline & Sengés & Sen & $24^{\circ} 16^{\prime} 46^{\prime \prime S}, 49^{\circ} 27^{\prime} 50^{\prime \prime W}$ & Guava \\
\hline & Itararé & Itr & $24^{\circ} 16^{\prime} 54^{\prime \prime} \mathrm{S}, 49^{\circ} 20^{\prime} 27^{\prime \prime} \mathrm{W}$ & Guava \\
\hline \multirow[t]{4}{*}{ Argentina } & Misiones & Misi & $27^{\circ} 23^{\prime} 59^{\prime \prime} \mathrm{S}, 55^{\circ} 56^{\prime} 01^{\prime \prime} \mathrm{W}$ & Guava \\
\hline & Concordia & Conc & $31^{\circ} 23^{\prime} 13^{\prime \prime} \mathrm{S}, 58^{\circ} 01^{\prime} 12^{\prime \prime} \mathrm{W}$ & Guava \\
\hline & Tucumán & Tucu & $27^{\circ} 02^{\prime} 18^{\prime \prime} \mathrm{S}, 65^{\circ} 19^{\prime} 13^{\prime \prime W}$ & Guava \\
\hline & Horco Molle & Hmol & $26^{\circ} 46^{\prime} 37^{\prime \prime} \mathrm{S}, 65^{\circ} 19^{\prime} 49^{\prime \prime W}$ & Guava \\
\hline \multirow[t]{2}{*}{ Peru } & La Molina & LMol & $12^{\circ} 14^{\prime} 15^{\prime \prime} \mathrm{S}, 76^{\circ} 31^{\prime} 50^{\prime \prime W}$ & Lab colony, cherimola (Annona cherimola) \\
\hline & Piura & Piur & $07^{\circ} 40^{\prime} 23^{\prime \prime} \mathrm{S}, 79^{\circ} 12^{\prime} 40^{\prime \prime} \mathrm{W}$ & Guava \\
\hline Ecuador & Guayaquil & 4Guy & $02^{\circ} 12^{\prime} 13^{\prime \prime S}, 79^{\circ} 53^{\prime} 50^{\prime \prime} \mathrm{W}$ & Guava \\
\hline Colombia & Tolimá & Toli & $04^{\circ} 26^{\prime} 11^{\prime \prime} \mathrm{N}, 75^{\circ} 11^{\prime} 29^{\prime \prime} \mathrm{W}$ & Lab colony, coffe (Coffea arabica) \\
\hline Guatemala & Guatemala City & Guat & $14^{\circ} 36^{\prime} 51^{\prime \prime} \mathrm{N}, 90^{\circ} 32^{\prime} 22^{\prime \prime} \mathrm{W}$ & Guava \\
\hline \multirow[t]{6}{*}{ Mexico } & Tapachula & Tapa & $14^{\circ} 53^{\prime} 47^{\prime \prime} \mathrm{N}, 92^{\circ} 24^{\prime} 31^{\prime \prime} \mathrm{W}$ & Guava; loquat (Eriobotrya japônica) \\
\hline & San Vicente & Vice & $16^{\circ} 24^{\prime} 16^{\prime \prime} \mathrm{N}, 92^{\circ} 10^{\prime} 30^{\prime \prime} \mathrm{W}$ & Guava \\
\hline & Quintana Roo & QRoo & $19^{\circ} 37^{\prime} 39^{\prime \prime N}, 88^{\circ} 38^{\prime} 56^{\prime \prime} \mathrm{W}$ & McPhail trap (adult flies) \\
\hline & Teocelo & Teoc & $19^{\circ} 23^{\prime} 14^{\prime \prime N}, 96^{\circ} 57^{\prime} 23^{\prime \prime W}$ & Guava \\
\hline & Apazapan & Apaz & $19^{\circ} 17^{\prime} 00^{\prime \prime} \mathrm{N}, 96^{\circ} 36^{\prime} 59^{\prime \prime} \mathrm{W}$ & McPhail trap (adult flies) \\
\hline & La Jicayana & Jica & $19^{\circ} 21^{\prime} 44^{\prime \prime} \mathrm{N}, 96^{\circ} 39^{\prime} 23^{\prime \prime} \mathrm{W}$ & Guava \\
\hline
\end{tabular}

sis (amino acid haplotypes) showed the existence 20 WSP alleles (Table 3) in the samples of the AF complex. Two alleles, wsp-31 and wsp-23, were already found in the Wolbachia Database. Wolbachia with wsp-31 (similar to wMel) was found in 69\% (176 out 255) of the individuals, being 76 in Brazilian-1, 36 in Brazilian-2, 39 in Brazilian-3, nine in Peruvian, three in Andean, and 13 in Mexican morphotypes. Bacteria harboring allele wsp-23 occurred in $4.8 \%$ of the individuals, and it was found in 11 individuals from three sampled populations of Brazilian-2 (Guaratuba, Pedro de Toledo, Ubatuba), and in three individuals of Brazilian-3 (Pedro de Toledo). Eighteen alleles not previously described, were found in Wolbachia infecting seven sampled populations of Brazilian-1, one in Brazilian-2, four in Brazilian-3, and six in samples from Mexican morphotypes. No double infection was found in single flies, but two Wolbachia harboring distinct wsp alleles were found in five sampled populations: two from Brazilian-3 (Pedro de Toledo: wsp-23, wsp-646; Salesópolis: wsp-31, wsp-647), and three from Mexican (Apazapan: wsp-650, wsp-651; San Vicente: wsp-31, wsp-
652; Tapachula: wsp-31, wsp-654) morphotypes (Table 3). Single synonymous and nonsynonymous nucleotide substitutions (Table S4) and very few gaps characterize the variability of the Wolbachia wsp gene in the morphotypes. Nucleotide variability of gene wsp within each morphotype was low, ranging from no substitution in Brazilian-3 to 0.0151 in the Mexican samples. Overall gene wsp showed a low variability in the Wolbachia samples from the neotropics (Table S2), reflecting in a low genetic distances of Wolbachia infecting the morphotypes, as showed in Table S3.

\section{Recombination between sequences}

Search for signatures of recombination was made between sequences of the five MLST genes and for gene wsp. The MLST genes were concatenated in order, gatB, $\operatorname{cox} A, h c p A, f t s Z$ and $f b p A[4,6]$, generating sequences of 2079 positions. A case of putative recombination was detected involving STs 329, 342 and $346(\mathrm{P} \ll 0.001$ detected by Maxchi, Geneconv and Chimaera), as shown in Fig. 2. 
Table 2

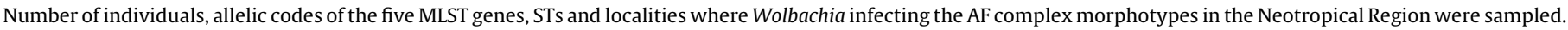

\begin{tabular}{|c|c|c|c|c|c|c|c|c|}
\hline \multirow[t]{2}{*}{ Morphotypes } & \multirow[t]{2}{*}{$\mathrm{N}$} & \multicolumn{5}{|c|}{ Alleles } & \multirow[t]{2}{*}{ ST } & \multirow[t]{2}{*}{ Localities of collection } \\
\hline & & gatB & $\operatorname{cox} A$ & hcpA & ftsZ & $f b p A$ & & \\
\hline \multirow[t]{9}{*}{ Brazilian-1 } & 76 & 1 & 1 & 1 & 1 & 1 & 1 & $\begin{array}{l}\text { 1Ara, 1Bot, 1Ibi, 1Itr,1Jac, } \\
\text { 1Jam, 1Lor, 1Pir, 1Isa, 1Slp, } \\
\text { 1Tri, 1Ube, 1Gua, 1Imb, 1Ira, 1Gum, 1Rne }\end{array}$ \\
\hline & 12 & 1 & 1 & 1 & 3 & 1 & 13 & 1Mir, 1Sal \\
\hline & 1 & 199 & 1 & 214 & 1 & 1 & $329^{a}$ & 1Jac \\
\hline & 1 & 200 & 190 & 1 & 3 & 257 & $330^{\mathrm{a}}$ & 1Sal \\
\hline & 5 & 1 & 1 & 1 & 162 & 1 & $331^{\mathrm{a}}$ & 1Sen \\
\hline & 3 & 1 & 1 & 1 & 1 & 261 & $342^{\mathrm{a}}$ & Conc \\
\hline & 5 & 1 & 1 & 1 & 167 & 262 & $343^{a}$ & $\mathrm{Hmol}$ \\
\hline & 2 & 1 & 1 & 1 & 168 & 263 & $344^{a}$ & Tucu \\
\hline & 2 & 203 & 1 & 1 & 1 & 264 & $345^{a}$ & Misi \\
\hline \multirow[t]{2}{*}{ Brazilian-2 } & 48 & 1 & 1 & 1 & 1 & 1 & 1 & 2Ber, 2Ilh, 2Ico, 2Ita, 2Pto, 2Per, 2Sse, 2Uba, 2Cai, 2Gut, 2Par \\
\hline & 4 & 1 & 1 & 1 & 3 & 1 & 13 & 2Tau \\
\hline \multirow[t]{4}{*}{ Brazilian-3 } & 45 & 1 & 1 & 1 & 1 & 1 & 1 & $\begin{array}{l}\text { 3Ber, 3Ico, 3Jam, 3Pto, 3Per, } \\
\text { 3Sal, 3Tau, 3Cai, 3Gut, 3Rne }\end{array}$ \\
\hline & 5 & 1 & 1 & 1 & 162 & 1 & $331^{\mathrm{a}}$ & 3Sal \\
\hline & 1 & 1 & 1 & 1 & 162 & 258 & $332^{\mathrm{a}}$ & 3Slp \\
\hline & 4 & 1 & 191 & 1 & 1 & 1 & $333^{a}$ & 3 Uba \\
\hline \multirow[t]{3}{*}{ Peruvian } & 2 & 1 & 1 & 1 & 1 & 1 & 1 & 4Guy \\
\hline & 2 & 1 & 1 & 217 & 1 & 260 & $341^{\mathrm{a}}$ & LMol \\
\hline & 5 & 1 & 1 & 1 & 1 & 261 & $342^{\mathrm{a}}$ & Piur \\
\hline Andean & 3 & 23 & 1 & 86 & 166 & 1 & $340^{\mathrm{a}}$ & Toli \\
\hline \multirow[t]{7}{*}{ Mexican } & 5 & 1 & 1 & 1 & 1 & 1 & 1 & Tapa \\
\hline & 4 & 1 & 1 & 1 & 164 & 1 & $335^{a}$ & Apaz \\
\hline & 1 & 201 & 1 & 215 & 164 & 1 & $336^{a}$ & Apaz \\
\hline & 8 & 1 & 1 & 1 & 165 & 1 & $337^{a}$ & Vice, Qroo \\
\hline & 4 & 1 & 1 & 216 & 164 & 259 & $338^{a}$ & Teoc \\
\hline & 3 & 202 & 192 & 1 & 1 & 1 & $339^{a}$ & Guat \\
\hline & 4 & 201 & 1 & 1 & 164 & 1 & $346^{a}$ & Jica \\
\hline
\end{tabular}

a Indicates new STs.

Table 3

Number of individuals, peptide code of HVRs, wsp alleles, and localities of collection of Wolbachia infecting the AF complex morphotypes in the Neotropical Region.

\begin{tabular}{|c|c|c|c|c|c|c|c|}
\hline \multirow[t]{2}{*}{ Morphotypes } & \multirow[t]{2}{*}{$\mathrm{N}$} & \multicolumn{4}{|c|}{ Peptide codes } & \multirow[t]{2}{*}{ wsp allele } & \multirow[t]{2}{*}{ Localities of collection } \\
\hline & & HVR1 & HVR2 & HVR3 & HVR4 & & \\
\hline \multirow[t]{8}{*}{ Brazilian-1 } & 76 & 1 & 12 & 21 & 24 & 31 & $\begin{array}{l}\text { 1Ara, 1Bot, 1Ibi, 1Itr, 1Jac } \\
\text { 1Jam, 1Lor, 1 Mir, 1Pir, 1Sal, 1Isa, 1Slp, 1Tri, 1Gua, } \\
\text { 1Gum, Conc, Hmol, Tucu }\end{array}$ \\
\hline & 5 & 218 & 252 & 21 & 24 & $640^{\mathrm{a}}$ & 1Ita \\
\hline & 4 & 1 & 255 & 21 & 278 & $641^{\mathrm{a}}$ & 1Ube \\
\hline & 5 & 1 & 225 & 21 & 278 & $642^{\mathrm{a}}$ & 1Sen \\
\hline & 5 & 1 & 12 & 21 & 245 & $643^{\mathrm{a}}$ & 1Rne \\
\hline & 2 & 225 & 12 & 21 & 19 & $656^{\mathrm{a}}$ & Misi \\
\hline & 5 & 226 & 253 & 21 & 277 & $658^{\mathrm{a}}$ & $1 \mathrm{Imb}$ \\
\hline & 5 & 1 & 12 & 21 & 278 & $659^{a}$ & 1Ira \\
\hline \multirow[t]{3}{*}{ Brazilian-2 } & 11 & 1 & 12 & 21 & 19 & 23 & 2Pto, 2Uba, 2Gut \\
\hline & 36 & 1 & 12 & 21 & 24 & 31 & $\begin{array}{l}\text { 2Ber, 2Ilh, 2Ico, 2Ita, 2Per, } \\
\text { 2Sse, 2Tau, 2Uba, 2Par }\end{array}$ \\
\hline & 5 & 1 & 12 & 21 & 279 & $645^{\mathrm{a}}$ & 2 Cai \\
\hline \multirow{6}{*}{ Brazilian-3 } & 3 & 1 & 12 & 21 & 19 & 23 & 3Pto \\
\hline & 39 & 1 & 12 & 21 & 24 & 31 & $\begin{array}{l}\text { 3Ber, 3Ico, 3Jam, 3Per, 3Sal } \\
\text { 3Slp, 3Tau, 3Uba, 3Cai }\end{array}$ \\
\hline & 2 & 1 & 12 & 21 & 280 & $646^{\mathrm{a}}$ & 3Pto \\
\hline & 1 & 1 & 12 & 21 & 281 & $647^{a}$ & 3Sal \\
\hline & 5 & 220 & 12 & 21 & 24 & $648^{\mathrm{a}}$ & 3Gut \\
\hline & 5 & 1 & 256 & 21 & 24 & $649^{a}$ & 3Rne \\
\hline Peruvian & 9 & 1 & 12 & 21 & 24 & 31 & 4Guy, Lmol, Piur \\
\hline Andean & 3 & 1 & 12 & 21 & 24 & 31 & Toli \\
\hline \multirow[t]{7}{*}{ Mexican } & 13 & 1 & 12 & 21 & 24 & 31 & Vice, Qroo, Tapa, Guat \\
\hline & 4 & 1 & 12 & 21 & 282 & $650^{\mathrm{a}}$ & Apaz \\
\hline & 1 & 1 & 12 & 257 & 283 & $651^{\mathrm{a}}$ & Apaz \\
\hline & 1 & 221 & 12 & 21 & 284 & $652^{\mathrm{a}}$ & Vice \\
\hline & 4 & 222 & 257 & 21 & 289 & $653^{a}$ & Jica \\
\hline & 2 & 223 & 258 & 21 & 286 & $654^{\mathrm{a}}$ & Tapa \\
\hline & 4 & 224 & 12 & 21 & 19 & $655^{a}$ & Teoc \\
\hline
\end{tabular}

a Indicates new wsp alleles. 


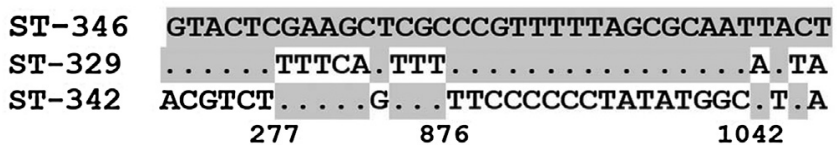

Fig. 2. Recombination detected among sequences of Wolbachia MLST genes infecting the AF complex. Only the polymorphic sites are shown in the alignment. Gray shaded parts of sequences are polymorfisms shared with the top sequence in the alignment. The numbers below the alignment indicate the approximate nucleotide position of the breakpoints detected by the three methods (Maxchi, Geneconv, Chimaera).

ST-329 was suggested as the putative recombinant, ST-346 as the major parent, and ST-342 the minor parent. Since three break points were detected two events of recombination may have occurred. Shuffling of a long segment from $5^{\prime}$ end of gene gat $B$ to the break point at position 1142 within gene $h c p A$ giving origin to the recombinant wsp-329, and two breaks, at position 277 (gene gatB) and 876 (gene $f t s Z$ ), interchanged a smaller segment between wsp-342 and the recombinant wsp-329.

Intragenic recombination between wsp alleles was tested following a procedure developed by Baldo et al. [7]. Fig. 3 shows the aligned amino acid sequences arranged according to similarities of HVR1, but differing in the other HVRs; three blocks of sequences were formed: one with novel sequences similar to wsp-31, one with new sequences similar to wsp-23, and a third one with a single novel sequence, wsp-653. As previously known, wsp-23 is an ancestral allele and differ from wsp-31 in their HVR4 [5,7]. Allele wsp-653 may be a recombinant having HVRs 2, 3 and 4 similar to those of wsp-23, but a distinct HVR1 of unknown origin. As wsp-653 is a new sequence detected in the present analysis it was not possible to determine its putative second parental sequence. Moreover, analysis of the nucleotide sequences by the three statistical methods of recombination detection did not indicate events of interchange between wsp-23, wsp-31 and the novel alleles, most probably due to the low divergence between them, a factor that precludes detection of recombination events according to the RDP3 manual. However, the analysis suggested, although not with strong statistical support $(\mathrm{P}=0.01)$, that wsp-653 may be a putative recombinant sequence.

\section{Phylogenetic analyses}

In the phylogenetic analyses that follow the putative recombinant sequences were not included since the Maximum Likelihood (ML) methodology requires sequences with the same evolutionary history $[42,64]$. Phylogenetic inference based on the concatenated set of the five MLST genes (Fig. 4) shows that Wolbachia strains detected in the samples of the six AF morphotypes grouped in a large cluster. Within this cluster no significant internal branching was observed indicating a close relationships among Wolbachia strains infecting the AF complex. This cluster is isolated from the strains of Wolbachia infecting other species of insects, including the fruit flies $B$. decurtans and B. tryoni. All these Wolbachia strains belong to supergroup A while Wolbachia infecting another species of Anastrepha, A. striata, is of supergroup B, as previously described [27]. Phylogenetic analysis based on the wsp gene revealed a similar set of results for Wolbachia infecting the AF complex morphotypes (Fig. 5). However, subgrouping could be further defined in future analyses based on whole genome basis, as is being pursued $[24,36,37]$.

\section{Discussion}

The present study showed that Wolbachia infection was found in $98 \%$ of flies belonging to the screened morphotypes of the $A$. fraterculus complex. This result, in line with previous report on infection in Brazilian morphotypes [12], places these species among those with high rate of infection $[19,20,61,64,68]$. In the six morphotypes of the AF complex here studied, 34 MLST alleles and 20 WSP alleles of Wolbachia were found. Hence, about 8.8 alleles/morphotype, against 137 alleles found in 42 species of other insects (3.7 alleles/species) [4] evidenced that, on average, the variability of Wolbachia in the AF complex is among the highest so far detected in insects.

In all samples of infected Anastrepha studied in this work, Wolbachia belonged to supergroup "A", as previously reported $[10,12]$. To date, only one sample of nominal $A$. fraterculus of unknown origin from South America were doubly infected with strains of supergroups "A" and "B" [10], and a sample of $A$. striata from Mexico was infected with Wolbachia supergroup "B" [27]. Hence, the data suggest that Anastrepha species seems to be more susceptible to infection by Wolbachia of supergroup "A", similar to what has been found in other dipteran species [54].

Variability of Wolbachia strains herein described shows two contrasting relationships with the regions along the Neotropical Region where the AF morphotype hosts were collected [17]. The most abundant strain, ST-1, was found spread from Brazil/Argentina through Mexico (except in the single sample from Colombia), clearly not exhibiting correlation with the geographic locations or the hosts, similarly observations on many dipteran species from distinct worldwide regions [54]. On the other hand, specific Wolbachia strains were found in most of the morphotypes indicating

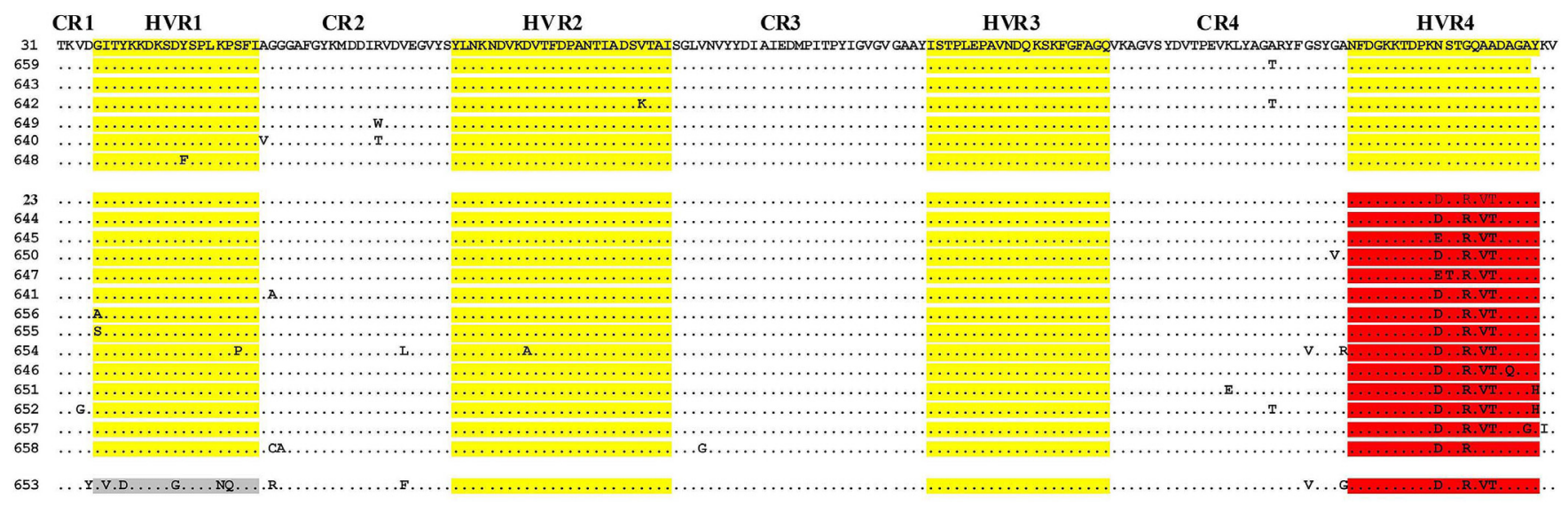

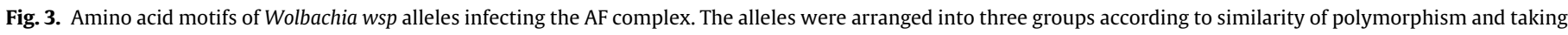
HVR1 of wsp-31, wsp-23 and wsp-653 as the reference for grouping. Each group of WSP alleles has unique combination of HVRs indicating shuffling of HVRs. 


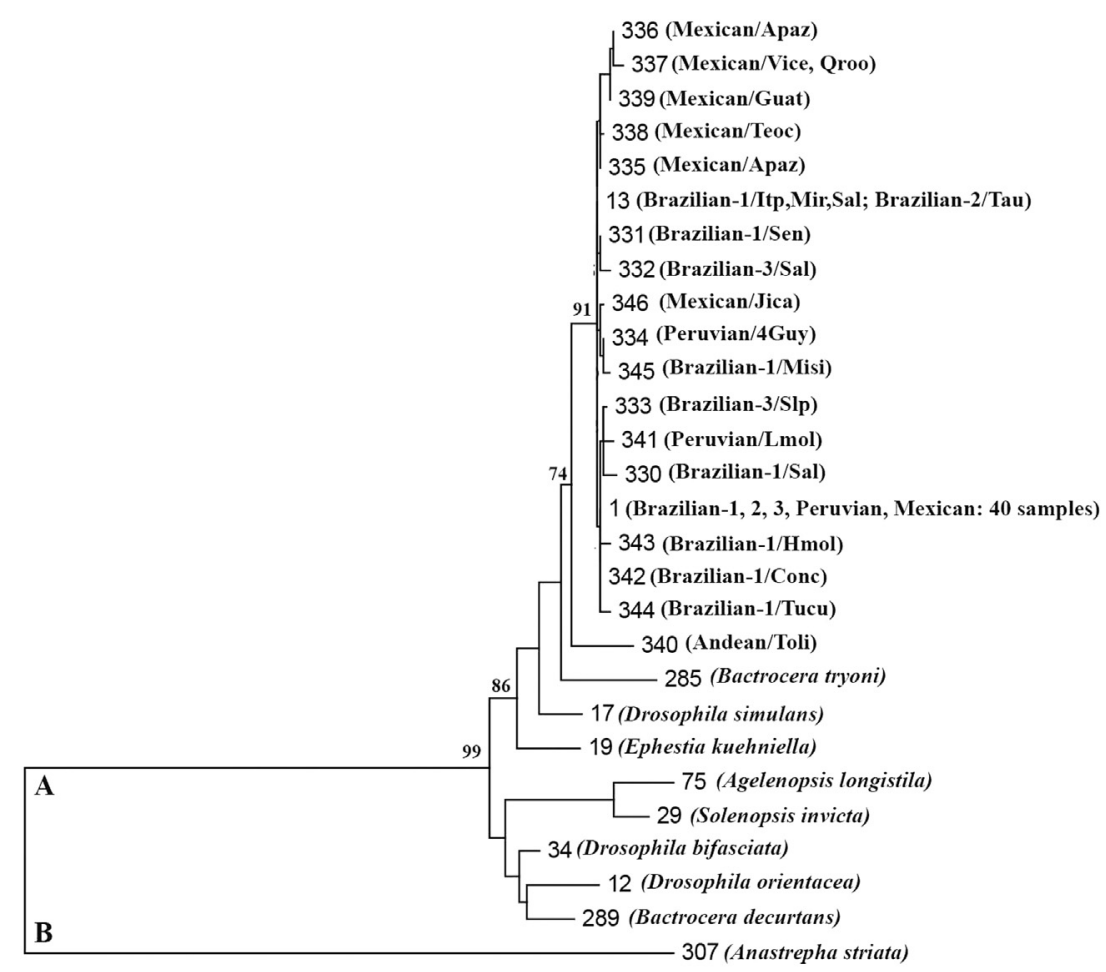

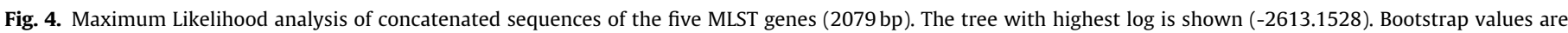

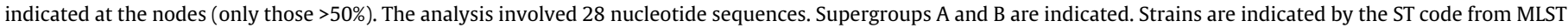

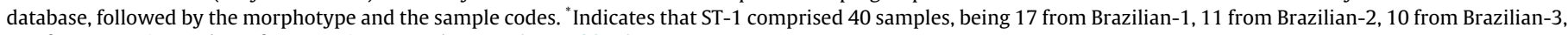
one from Peruvian and one from Mexican morphotypes (see Table 2).

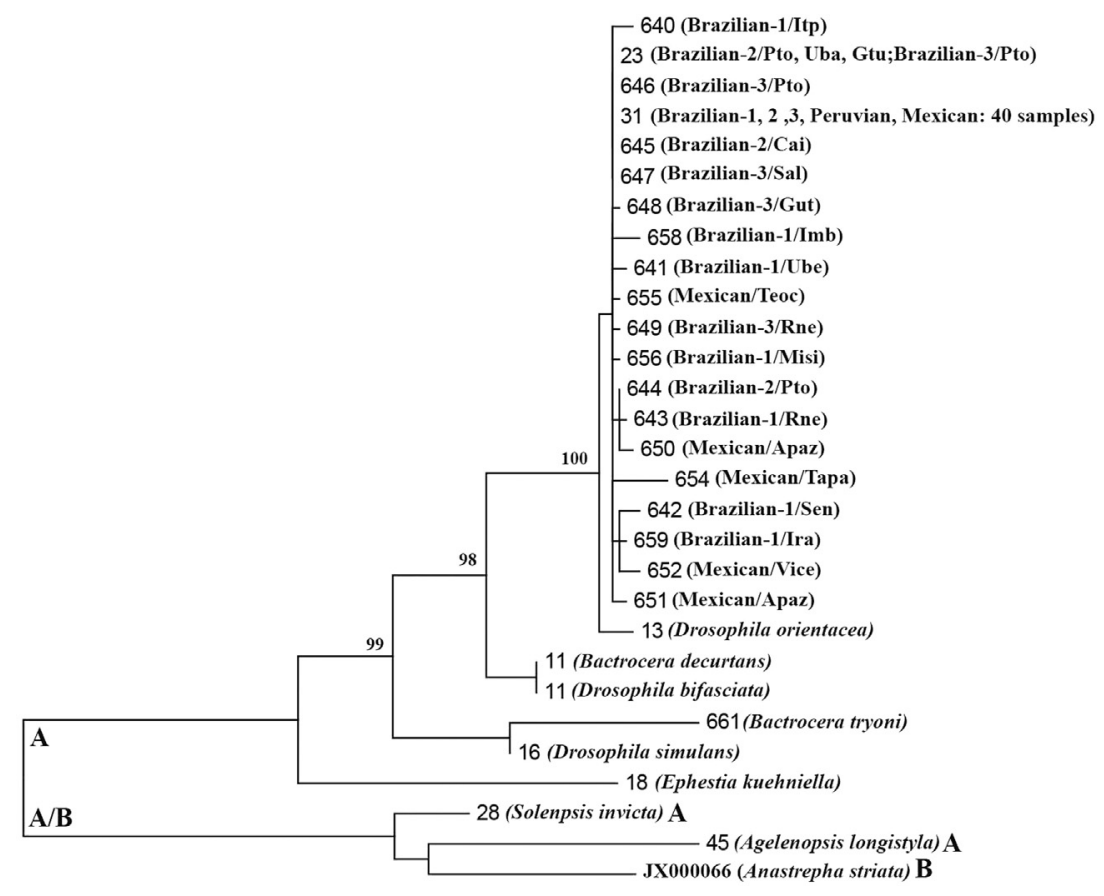

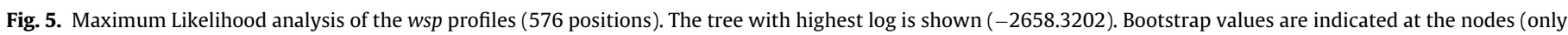

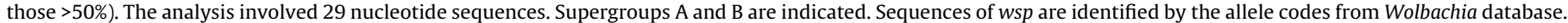

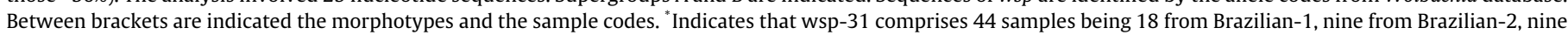
from Brazilian-3, three from Peruvian, one from Andean and four from Mexican morphotypes (see Table 3).

a close relationship between strain types and their fly hosts. This type of association was also found, for example, in fig wasps from Panama and Australia [16], in ants from the New and Old World [41], in the testacea complex of Drosophila from North America,
Europe and Asia, and in two chloropid flies from North America [54]. The cause of the continental wide distribution of some Wolbachia strains within the AF complex is unknown. It may be considered that the wide spread Wolbachia strains in the AF com- 
plex are extant forms of ancient origins, while the unique, specific strains might have evolved by mutational events and/or horizontal transmission. The low variability existing in the strains suggests that the differences could be the result of mutations, similarly to the case of strains in Rhagoletis pomonella [44]. However, the presence of identical strains in zones of host sympatry, for example, ST-13 in Brazilian-1 (1Mir, 1Sal) and Brazilian-2 (2Tau) morphotypes, suggested that horizontal transmission may not be excluded. Evidences of this kind of transmission was found for Wolbachia infecting species of Bactrocera [30], and between species of Anastrepha and of parasitoid braconid wasps [28]. Another scenario would be to suppose that these strains were relics of ancient forms before the splitting of the fraterculus complex morphotypes.

The results reinforce that phylogenetic reconstruction based on single genes do not represent accurately the relationship between the bacteria strains. Moreover, the MLST methodology efficiently characterize Wolbachia strains, as shown in other groups of insects, including the fruit flies as previously demonstrated $[2,3,8,20,27,30,31,44]$. However, the results show that analysis of $w s p$ is very useful to reveal groups of close related individual strains, as usually observed in other insects $[5,21,54]$. This is relevant since the mosaic nature of genes coding for surface proteins, such as the $w s p$, may be responsible for the appearance of new phenotypes that could lead to distinctive interactions of parasitic strains with their insect hosts $[5,6,7,52,61]$. Novel haplotypes resulting from inter or intragenic recombination may also increase the number of Wolbachia strains $[3,7,21]$. Even though the present data show that recombination events were not frequent within the bacteria infecting the AF complex, the results suggested the presence of a putative recombinant allele, wsp-653, among the 18 novel described $w s p$ haplotypes, and a single signature of putative intergenic recombination involving the MLST genes. This is in line with previous surveys showing that recombination between MLST genes and intragenic recombination of gene wsp are found in Wolbachia infecting many insect species $[4,6]$.

In conclusion, and additionally to previous observations [10,12], the results of the present analyses show that the morphotypes of the A. fraterculus complex actually harbor distinct strains of Wolbachia. Under the presumption that Wolbachia may induce cytoplasmatic incompatibility in Anastrepha, such as demonstrated in other fruit fly species $[1,38,65,66]$, the detection of specific strains associated with distinct morphotypes leads to the suggestion that Wolbachia may have acted as a reinforcing factor in the diversification processes of the A. fraterculus complex.

\section{Acknowledgments}

The present study was supported by a grant from Fundação de Amparo à Pesquisa do Estado de São Paulo, Brazil (Proc. 2010/52040-8) to DS, and a partial support by the International Atomic Energy Agency, Insect Pest Control Subprogramme (Vienna, Austria) under research contract IAEA-16080/R0 to VHO. LFP had a doctoral scholarship from CAPES and DS had a fellowship from CNPq.

\section{Appendix A. Supplementary data}

Supplementary data associated with this article can be found, in the online version, at http://dx.doi.org/10.1016/j.syapm.2016.11. 002.

\section{References}

[1] Apostolaki, A., Livadaras, I., Saridaki, A., Chrysargyris, A., Savakis, C., Bourtzis, K. (2011) Transinfection of the olive fruit fly Bactrocera oleae with Wolbachia: towards a symbiont-based population control strategy. J. Appl. Entomol. 135, $546-555$.

[2] Arthofer, W., Riegler, M., Schneider, D., Krammer, M., Miller, W.J., Stauffer, C. (2009) Hidden Wolbachia diversity in field populations of the European cherry fruit fly, Rhagoletis cerasi (Diptera, Tephritidae). Mol. Ecol. 18, 3816-3830.

[3] Augustinos, A.A., Asimakopoulou, A.K., Moraiti, C.A., Mavragani-Tsipidou, P. Papadopoulos, N.T., Bourtzis, K. (2014) Microsatellite and Wolbachia analysis in Rhagoletis cerasi natural populations: population structuring and multiple infections. Ecol. Evol. 4, 1943-1962.

[4] Baldo, L., Bordenstein, S., Wernegreen, J.J., Werren, J.H. (2006) Widespread recombination throughout Wolbachia genomes. Mol. Biol. Evol. 23, 437-449.

[5] Baldo, L., Desjardins, C.A., Russell, J.A., Stahlhut, J.K., Werren, J.H. (2010) Accelerated microevolution in an outer membrane protein (OMP) of the intracellular bacteria Wolbachia. BMC Evol. Biol. 10, 48.

[6] Baldo, L., Dunning-Hotopp, J.C., Jolley, K.A., Bordenstein, S., Biber, A.S., Choudhury, R.R., Hayashi, C., Maiden, M.C.J., Tettelin, H., Werren, J.H. (2006) Multilocus sequence typing system for the endosymbiont Wolbachia pipientis. Appl. Environ. Microbiol. 72, 7098-7110.

[7] Baldo, L., Lo, N., Werren, J.H. (2005) Mosaic nature of the Wolbachia surface protein. J. Bacteriol. 187, 5406-5418.

[8] Baldo, L., Werren, J.H. (2007) Revisiting Wolbachia supergroup typing based on wsp: spurious lineages and discordance with MLST. Curr. Microbiol. 55, 81-87.

[9] Bourtzis, K., Braig, H.R., Karr, T.L. (2003) Cytoplasmic incompatibility. In: Bourtzis, K., Miller, T.A. (Eds.), Insect symbiosis, CRC Press, Boca Raton, pp. 217-246.

[10] Cáceres, C., Segura, D.F., Vera, M.T., Wornoayporn, V., Cladera, J.L., Teal, P. Sapountzis, P., Bourtzis, K., Zacharopoulou, A., Robinson, A.S. (2009) Incipient speciation revealed in Anastrepha fraterculus (Diptera: Tephritidae) by studies on mating compatibility, sex pheromones, hybridization, and cytology. Biol. J. Linn. Soc. 97, 152-165.

[11] Canal, N.A., Hernández-Ortiz, V., Salas, J.O.T., Selivon, D. (2015) Morphometric study of third-instar larvae from five morphotypes of the Anastrepha fraterculus cryptic species complex (Diptera, Tephritidae), in: De Meyer, M., Clarke, A.R., Hendrichs, J. (Eds.), Resolution of cryptic species complexes of tephhritidae pests to enhance sit application and facilitate international trade, 540, ZooKeys, pp. 41-59.

[12] Coscrato, V.E., Braz, A.S.K., Perondini, A.L.P., Selivon, D., Marino, C.L. (2009) Wolbachia in Anastrepha fruit flies (Diptera, Tephritidae). Curr. Microbiol. 59, 295-301.

[13] Devescovi, F., Abraham, S., Roriz, A.K., Nolazco, N., Castañeda, R., Tadeo, E., Cáceres, C., Segura, D.F., Vera, M.T., Joachin-Bravo, I., Canal, N., Rull, J. (2014) Ongoing speciation within the Anastrepha fraterculus cryptic species complex: the case of the Andean morphotype. Entomol. Exp. Appl. 152, 238-247.

[14] Dias, V.S., Silva, J.G., Lima, K.M., Pettinga, C.S.C.D., Hernández-Ortiz, V., Laumann, R.A., Paranhos, B.J., Uramoto, K., Zucchi, R.A., Joachin-Bravo, I.S. (2016) An integrative multidisciplinary approach to understanding cryptic divergence in Brazilian species of the Anastrepha fraterculus complex (Diptera: Tephhritidae). Biol. J. Linn. Soc. 117, 725-746.

[15] Guindon, S., Dufayard, J.F., Lefort, V., Anisimova, M., Hordijk, W., Gascuel, O. (2010) New algorithms and methods to estimate maximum-likelihood phylogenies: assessing the performance of PhyML 3.1. Syst. Biol. 59, 307-321.

[16] Haine, E.R., Cook, J.M. (2005) Convergent incidences of Wolbachia infection in fig wasp communities from two continents. Proc. R. Soc. Lond. B 272, 421-429.

[17] Hernández-Ortiz, V., Bartolucci, A.F., Morales-Valles, P., Frías, D., Selivon, D. (2012) Cryptic species of the Anastrepha fraterculus complex (Diptera: Tephritidae): a multivariate approach for the recognition of South American morphotypes. Ann. Entomol. Soc. Am. 105, 305-318.

[18] Hernández-Ortiz, V., Canal, N.A., Tigrero, J.O., Ruíz-Hurtado, F.M., Dzul-Cauich, J.F. (2015) Taxonomy and phenotypic relationships of the Anastrepha fraterculus complex in the Meso-American and Pacific Neotropical dominions (Diptera, Tephritidae), in: De Meyer, M., Clarke, A.R., Hendrichs, J. (Eds.), Resolution of cryptic species complexes of tephhritidae pests to enhance sit application and facilitate international trade, 540, ZooKeys, pp. 75-124.

[19] Hilgenboecker, H., Hammerstein, P., Schlattmann, P., Telschow, A., Werren, J.H. (2008) How many species are infected with Wolbachia?-A statistical analysis of current data. FEMS Microbiol. Lett. 281, 215-220.

[20] Jeyaprakash, A., Hoy, M.A. (2000) Long PCR improves Wolbachia DNA amplification: wsp sequences found in $76 \%$ of sixty-three arthropod species. Insect Mol. Biol. 9, 393-405.

[21] Jiggins, F.M., van der Schulenburg, J.H., Hust, G.G., Majerus, M.E. (2001) Recombination confounds interpretations of Wolbachia evolution. Proc. R. Soc. Lond. B 268, 1423-1427.

[22] Karimi, J., Darsouei, R. (2014) Presence of the endosymbiont Wolbachia among some fruit flies (Diptera: Tephritidae) from Iran: a multilocus sequence typing approach. J. Asia-Pacific Entomol. 17, 105-112.

[23] Librado, P., Rozas, J. (2009) DnaSP v5: a software for comprehensive analysis of DNA polymorphism. Bioinformatics 25, 1451-1452.

[24] Lindsey, A.R.L., Bordenstein, S.R., Newton, I.L.G., Rasgon, J.L. (2016) Wolbachia pipientis should not be split into multiple species; A response to RamírezPuebla et al., Species in Wolbachia? Proposal for the designation of 'Candidatus Wolbachia bourtzisii' 'Candidatus Wolbachia onchocercicola' 'Candidatus Wolbachia blaxteri, Candidatus Wolbachia brugii, 'Candidatus Wolbachia taylori', 'Candidatus Wolbachia collembolicola', 'Candidatus Wolbachia multihospitum' for the different species within Wolbachia supergroups. Syst. Appl Microbiol. $39,220-222$. 
[25] Marcon, H.S., Coscrato, V.E., Selivon, D., Perondini, A.L.P., Marino, C.L. (2011) Variations on the sensitivity of different primers for detecting Wolbachia in Anastrepha (Diptera, Tephritidae). Braz. J. Microbiol. 42, 778-785.

[26] Martin, D., Rybicki, E. (2000) RDP: detection of recombination among aligned sequences. Bioinformatics 16, 562-563.

[27] Martínez, H., Toledo, J., Liedo, P., Mateos, M. (2012) Survey of heritable endosymbionts in southern Mexico populations of the fruitfly species Anastrepha striata and A ludens. Curr. Microbiol. 65, 711-718.

[28] Mascarenhas, R.O., Prezotto, L.F., Perondini, A.L.P., Marino, C.L., Selivon, D. (2016) Wolbachia in guilds of Anastrepha fruit flies (Tephritidae) and parasitoid wasps (Braconidae). Genet. Mol. Biol., http://dx.doi.org/10.1590/1678-4685GMB-2016-0075, Ahead of print.

[29] Maynard Smith, J. (1992) Analyzing the mosaic structure of genes. J. Mol. Evol. 34, 126-129.

[30] Morrow, J.L., Frommer, M., Royeer, J.E., Shearman, D.C.A., Riegler, M. (2015) Wolbachia pseudogenes and low prevalence infections in tropical but not temperate Australian tephritid fruit flies: manifestations of lateral gene transfer and endosymbiont spillover? BMC Evol Biol. 15, 202.

[31] Morrow, J.L., Frommer, M., Shearman, D.C.A., Riegler, M. (2014) Tropical tephritid fruit fly community with high incidence of shared Wolbachia strains as platform for horizontal transmission of endosymbionts. Environ. Microbiol. 16, 3622-3637.

[32] Norrbom, A.L., Korytkowski, C.A., Zucchi, R.A., Uramoto, K., Venable, G.L., McCormick, J., Dallwitz, M.J. 2012 Anastrepha and Toxotrypana: descriptions, illustrations and interactive keys , Version: 28th September 2013. http://deltaintkey.com/anatox/indext.htm (Accessed 05 January 2015).

[33] Padidam, M., Sawyer, S., Fauquet, C.M. (1999) Possible emergence of new gemini viruses by frequent recombination. Virology 265, 218-225.

[34] Paraskevopoulos, C., Bordenstein, S.R., Wernegreen, J., Werren, J.H., Bourtzis, K. (2006) Towards a Wolbachia multi locus strain typing system: discrimination of Wolbachia strains present in Drosophila species. Curr. Microbiol. 53, 388-395.

35] Posada, D., Crandall, K.A. (2001) Evaluation of methods for detecting recombination from DNA sequences: computer simulations. Proc. Natl. Acad. Sci. U. S. A. $98,13757-13762$

[36] Ramírez-Puebla, S.T., Servin-Garcidueñas, L.E., Ormeño-Orrillo, E., de Leon, A. Vera-Ponce, Rosenblueth, M., Delaye, L., Martínez, J., Martínez-Romewro, E. (2016) Species in Wolbachia? Proposal for the designation of 'Candidatus Wolbachia bourtzisii', 'Candidatus Wolbachia onchocercicolan', 'Candidatus Wolbachia blaxteri, Candidatus Wolbachia brugii', 'Candidatus Wolbachia taylorin', 'Candidatus Wolbachia collembolicolan', 'Candidatus Wolbachia multihospitumn' for the different species within Wolbachia supergroups. Syst. Appl. Microbiol. 38, 390-399.

[37] Ramírez-Puebla, S.T., Servin-Garcidueñas, L.E., Ormeño-Orrillo, E., Vera-Ponce de Leon, A., Rosenblueth, M., Delaye, L., Martínez, J., Martínez-Romewro, E. (2016) A response to Lindsey et al. Wolbachia pipientis should not be split into multiple species: a response to Ramírez-Puebla, et al. Syst. Appl. Microbiol. 39, $223-225$.

[38] Riegler, M., Stauffer, C. (2002) Wolbachia infections and superinfections in cytoplasmically incompatible populations of the European cherry fruit fly Rhagoletis cerasi (Diptera, Tephritidae). Mol. Ecol. 11, 2425-2434.

[39] Rocha, L.S., Mascarenhas, R.O., Perondini, A.L.P., Selivon, D. (2005) Occurrence of Wolbachia in brazilian samples of Ceratitis capitata (Wiedemann) (Diptera Tephritidae). Neotrop. Entomol. 32, 527-529.

[40] Rull, J., Abraham, S., Kovaleski, A., Segura, D.F., Mendonza, M., Liendo, M.C., Vera, M.T. (2013) Relative importance of prezygotic and postzygotic barriers to gene flow among three cryptic species within the Anastrepha fraterculus complex. Entomol. Exp. Appl. 148, 213-222.

[41] Russell, J.A., Goldman-Huertas, B., Moreau, C.S., Baldo, L., Stahlhut, J.K., Werren, J.H., Pierce, N.E. (2009) Host specificity and geographic isolation among Wolbachia from ants and butterflies. Evolution 63, 624-640.

[42] Sanglas, A., Albarral, V., Farfãm, M., Lorén, J.G., Fusté, M.C. (2016) Direct evidence of recombination in the recA gene of Aeromonas bestiarum. Syst. App. Microbiol. 39, 106-114.

[43] Saridaki, A., Bourtzis, K. (2010) Wolbachia: more than just a bug in insect genitals. Curr. Opin. Microbiol. 13, 67-72.

[44] Schuler, H., Wolfgang, A., Riegler, M., Bertheau, C., Krumböck, S., Köppler, K. Vogt, H., Teixeira, L.A., Stauffer, C. (2011) Multiple Wolbachia infections in Rhagoletis pomonella. Entomol. Exp. Appl. 139, 138-144.

[45] Segura, D.E., Vera, M.T., Rull, J., Wornoaypong, V., Islam, A., Robinson, A.S (2011) Assortative mating among Anastrepha fraterculus (Diptera: Tephritidae) hybrids from two distinct populations as a possible route to radiation of the fraterculus cryptic species group. Biol. J. Linn. Soc. 102, 346-354.

[46] Selivon, D., Perondini, A.L.P. (1998) Eggshell morphology in two cryptic species of Anastrepha fraterculus (Diptera: Tephritidae). Ann. Entomol. Soc. Am. 91, 473-478.
[47] Selivon, D., Perondini, A.L.P. (2007) Especies crípticas del complejo Anastrepha fraterculus en Brasil. In: Hernández-Ortiz, V. (Ed.), Moscas de la Fruta en Latinoamérica (Diptera: Tephritidae): Diversidad, biología y manejo, S y G Editores, Distrito Federal, México, pp. 101-118.

[48] Selivon, D., Perondini, A.L.P., Morgante, J.S. (1999) Haldane’s rule and other aspects of reproductive isolation observed in the Anastrepha fraterculus complex (Diptera, Tephhritidae). Genet. Mol. Biol. 22, 507-510.

[49] Selivon, D., Perondini, A.L.P., Morgante, J.S. (2005) A genetic-morphological characterization of two cryptic species of the Anastrepha fraterculus complex (Diptera, Tephritidae). Ann. Entomol. Soc. Am. 98, 367-381.

[50] Selivon, D., Perondini, A.L.P., Ribeiro, A.F Marino, C.L. Lima, M.M.A. Coscrato, V.E. (2002) Wolbachia endosymbiont in a species of the Anastrepha fraterculus complex (Anastrepha: Diptera: Tephritidae). Invertebr. Reprod. Dev. 42, 121-127.

[51] Selivon, D., Vretos, C., Fontes, L., Perondini, A.L.P. (2004) New variant forms in the Anastrepha fraterculus complex. In: Barnes, B. (Ed.), Proc 6th International Fruit Flies Symposium, Isteg Scientific Publications, Irene, South Africa, pp. 253-258.

[52] Serbus, L.R., Casper-Lindley, C., Landmann, F., Sullivan, W. (2008) The genetics and cell biology of Wolbachia-host interactions. Annu. Rev. Genet. 42, 683-707.

[53] Sievers, F., Wilm, A, Dineen, D.G., Gibson, TJ., Karplus, K, Li, W., Lopez, R. McWilliam, H., Remmert, M., Söding, J., Thompson, J.D., Higgins, D.G. (2011) Fast, scalable generation of high-quality protein multiple sequence alignments using Clustal Omega. Mol. Syst. Biol. 7, 539

[54] Stahlhut, J.K., Dejardin, C.A., Clark, M.E., Baldo, L., Russel, J.A., Werren, J.H. (2010) The mushroom habitat as an ecological arena for global exchange of Wolbachia. Mol. Ecol. 19, 1940-1952.

[55] Sutton, B.D., Steck, G.J., Norrbom, A.L., Rodrigues, E.J. (2015) Nuclear ribosomal internal trsnacribed spacer I (ITS1) variation in the Anastrepha fraterculus cryptic species complex (Diptera, Tephritidae) of the Andean region, in: De Meyer M., Clarke, A.R., Hendrichs, J. (Eds.), Resolution of cryptic species complexes of tephhritidae pests to enhance sit application and facilitate international trade, 540, ZooKeys, pp. 175-191.

[56] Tamura, K., Stecher, G., Peterson, D., Filipski, A., Kumar, S. (2013) MEGA 6: molecular evolutionary genetics analysis version 6.0. Mol. Biol. Evol. 30, 2725-2729.

[57] Togawa, R.C., Brigido, M.M. (2003) PHPH: Web based tool for simple electropherogram quality analysisL. In: 1st International Conference on Bioinformatics and Computational Biology, 14th to 16th May, Ribeirão Preto, http://asparagin. cenargen.embrapa.br/phph/ (Assessed April 23 2016).

[58] Vanícková, L., Hernádez-Ortiz, V., Joachin-Bravo, I.S., Dias, V., Roriz, A.K.P., Laumann, R.A., Mendonça, A.L., Paranhos, B.A.J., Nascimento, R.R. (2015) Current knowledge of the species complex Anastrepha fraterculus (Diptera, Tephritidae) in Brazil, in: De Meyer, M., Clarke, A.R., Hendrichs, J. (Eds.), Resolution of cryptic species complexes of tephhritidae pests to enhance sit application and facilitate international trade, 540, ZooKeys, pp. 211-237.

[59] Vera, M.T., Cáceres, C., Wornoyapor, V., Islam, A., Robinson, A.S., de la Vega, M., Hendrichs, J., Cayol, J.P. (2006) Mating incompatibility among populations of the South American fruit fly Anastrepha fraterculus (Diptera, Tephritidae). Ann. Entomol. Soc. Am. 99, 387-397.

[60] Werren, J.H. (1997) Biology of Wolbachia. Annu. Rev. Entomol. 42, 587-609.

[61] Werren, J.H., Baldo, L., Clark, M.E. (2008) Wolbachia: master manipulators of invertebrate biology. Nat. Rev. Microbiol. 6, 741-751.

[62] Werren, J.H., Windsor, D., Guo, L.R. (1995) Distribution of Wolbachia among neotropical arthropods. Proc. R. Soc. Lond. B 262, 197-204

[63] White, I.M., Elson-Harris, M.M. 1992 Fruit flies of economic significance: their identification and bionomics, CAB International, Wallingford, UK.

[64] Yang, C.-Y., Xiao, J.-H., Niu, L.-M., Ma, G.-C., Cook, J.M., Sheng-Nan, B., YueGuan, F., Da-Wei, H. (2012) Chaos of Wolbachia sequences inside the compact fig syconia of Ficus benjamina (Ficus: Moraceae). PLoS One 7 (11), e48882.

[65] Zabalou, S., Riegler, M., Theodorakopoulou, M., Stauffer, C., Savakis, C., Bourtzis, K. (2004) Wolbachia-induced cytoplasmic incompatibility as a means for insect pest population control. Proc. Nat. Acad. Sci. 101, 15042-15045.

[66] Zabalou, S., Apostolaki, A., Livadaras, I., Franz, G., Robinson, A.S., Savakis, C. Bourtzis, K. (2009) Incompatible insect technique: incompatible males from a Ceratitis capitata genetic sexing strain. Entomol. Exp. Appl. 132, 232-240.

[67] Zhou, W., Rousset, F., O’Neill, S. (1998) Phylogeny and PCR-based classification of Wolbachia strains using wsp gene sequences. Proc. R. Soc. Lond. B 265 509-515.

[68] Zug, R., Hammerstein, P. (2012) Still a host of hosts for Wolbachia: analysis of recent suggests that $40 \%$ of terrestrial arthropod species are infected. PLoS One 7 (6), e79825843. 